\title{
Fabryka zbrojeniowa Dynamit Aktien Gesellschaft w Krzystkowicach (Christianstadt). Historia do napisania od nowa
}

\author{
Wojciech Eckert \\ Instytut budownictwa, Wydziat Budownictwa, Architektury i inżynierii Środowiska, \\ Uniwersytet Zielonogórski,e-mail:w.eckert@ib.uz.zgora.pl
}

Streszczenie: W województwie lubuskim znajduje się duża ilość zabytkowych obiektów fortyfikacyjnych oraz związanych z przemysłem zbrojeniowym. Zbudowane w pierwszej połowie XX w., w konstrukcji betonowej, utraciły swoje pierwotne funkcje i charakter. Niezagospodarowane ulegają powolnemu niszczeniu. Jednym z nich jest tzw. „Fabryka Dynamitu", zespół ok. 300 budowli rozrzuconych na porośniętym lasem terenie o powierzchni $35 \mathrm{~km}^{2}$, niedaleko Nowogrodu Bobrzańskiego, ok. $20 \mathrm{~km}$ na południe od Zielonej Góry. Część z nich po II wojnie światowej została wysadzona w powietrze. Jednak wiele z nich do dzisiaj zachowało się w dobrym stanie technicznym.

Nie powstały dotychczas poważniejsze, kompleksowe opracowania dotyczące „Fabryki Dynamitu" w Krzystkowicach, zarówno historyczne jak i architektoniczne czy urbanistyczne. Nie ma również pomysłu dotyczącego możliwości i sposobu adaptacji reliktów fabryki dla współczesnych celów.

W artykule podjęto próbę opisu tego wielkiego kompleksu fabrycznego. Wskazano również na wyjątkowość tego zespołu budowli nie tylko w skali województwa ale w skali regionu. Powinien powstać kompleksowy program adaptacji, modernizacji i nowego, racjonalnego zagospodarowania reliktów fabryki.

Wokół takiego programu można skupić, zarówno krajowe jak i europejskie, jednostki naukowe, pracownie architektoniczno-urbanistyczne, uczelnie, jednostki samorządowe i wiele innych. Fabryka zbrojeniowa Dynamit Aktien Gesellschaft w Krzystkowicach (Christianstadt) czeka na ponowne, tym razem pokojowe wykorzystanie.

Słowa kluczowe: zabytek, fabryka dynamitu, adaptacja, modernizacja, zagospodarowanie terenu.

\section{Wprowadzenie}

Zakłady Dynamit Aktien Gesellschaft (wcześniej Alfred Nobel \& Co.), zostały zlokalizowane obok dawnych Krzystkowic (Christianstadt), położonych na lewym brzegu Bobru, dziś włączonych do miasteczka Nowogród Bobrzański. Tereny, na których znajdował się kombinat, porasta las ciągnący się od Nowogrodu Bobrzańskiego w kierunku północnym aż do wioski Dachów. Komunikację wewnętrzną kompleksu umożliwia sieć betonowych dróg. Obiekty kombinatu są położone na obszarze o powierzchni około $35 \mathrm{~km}^{2}$ i częściowo zajęte przez jednostkę wojskową oraz zakład karny. Dojazd do pozostałości fabryki znajduje się przy drodze krajowej nr 289 Nowogród Bobrzański - Lubsko, kilkaset metrów za przejazdem kolejowym. 


\section{Historia}

Odtworzenie historii budowy i zakresu działalności fabryki jest bardzo utrudnione ze względu na brak źródeł, zarówno pisanych, jak i ikonograficznych. Prawdopodobnie cała dokumentacja została wywieziona pod koniec drugiej wojny światowej przez wycofujących się z Krzystkowic Niemców, bądź przejęta przez wojska radzieckie. Z konieczności informacje historyczne muszą opierać się na nielicznych publikacjach o charakterze regionalnym.

Budowę zakładów w Christianstadt rozpoczęto najprawdopodobniej w 1938 roku. W tym czasie w miejscowości funkcjonowała już filia koncernu Dynamit Aktien Gesellschaft. Przy budowie tej jednej z największych europejskich fabryk zbrojeniowych zatrudniono około 25 tysięcy robotników przymusowych, pochodzących z podbitych przez Rzeszę Niemiecką krajów: Belgii, Czech, Francji, Holandii, Jugosławii, Rosji, Słowacji, Ukrainy, Włoch i Polski. Dokładna liczba więźniów budujących fabrykę i pracujących przy produkcji zbrojeniowej nie jest znana. Ocenia się, że w różnych okresach pracowało tutaj od 20 do 40 tysięcy ludzi.

Fabryka w Krzystkowicach wraz z innymi zakładami DAG podlegała ministrowi uzbrojenia i produkcji wojennej Rzeszy, profesorowi Albertowi Speerowi. Została zbudowana od podstaw z zastosowaniem najnowoczesniejszych technologii. Wcześniej zlikwidowano wioski znajdujące się w rejonie planowanej inwestycji. Kompleks leśny otoczono podwójnym ogrodzeniem z drutu kolczastego. Obiekty fabryczne były budowane na miejscu karczowanego lasu. Na obszarze $35 \mathrm{~km}^{2}$ zbudowano kilkaset obiektów. Były to zarówno obiekty naziemne, jak i różnego typu instalacje podziemne, tunele, baseny, zbiorniki służące do przechowywania substancji wybuchowych. W trakcie budowy zakładów powstało wiele obiektów towarzyszących. Zbudowano dwa ujęcia wody na Bobrze oraz studnie głębinowe, a także sieć wodociągową, kanalizacyjną i energetyczną. Powstał skomplikowany system komunikacyjny, składający się z wielu utwardzonych dróg oraz linii kolejowej z bocznicami, rozjazdami i rampami przeładunkowymi. Fabryka miała własną straż pożarną z kompletnym zapleczem technicznym.

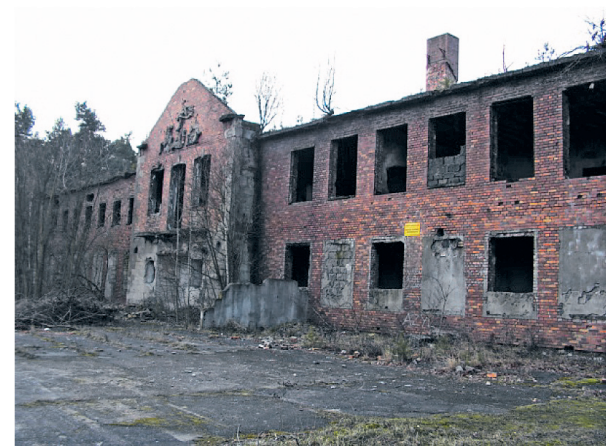

Fot. 1. Budynek dyrekcji fabryki

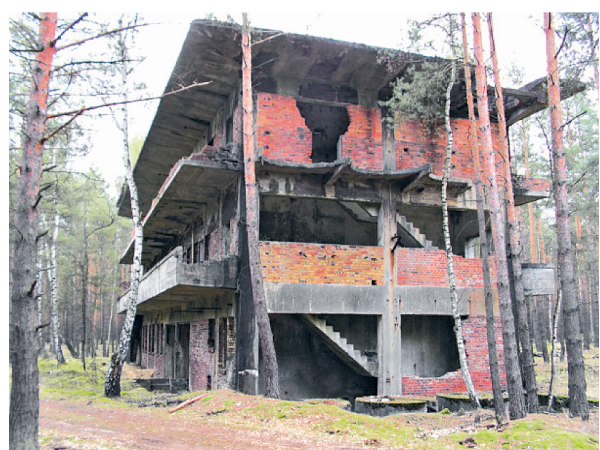

Fot. 2. Budynek laboratorium

Na początku na potrzeby fabryki pracowała elektrownia wodna zasilana przez Bóbr. Na przełomie 1943 i 1944 roku uruchomiono nową elektrociepłownię z dwoma blokami energetycznymi. System energetyczny był wyposażony także w awaryjne źródło zasilania. Były to bloki spalinowych zespołów prądotwórczych. W skład kompleksu elektrociepłowniczego wchodziły pochylnie do transportu opału z zespołem silosów umieszczonych nad halą pieców, które znajdowały się obok obiektu z turbinami. W elektrociepłowni znajdowało się biuro ekspedycji kolejowej, laboratoria do badania jakości opału oraz wody, a także zaplecze socjalne. 


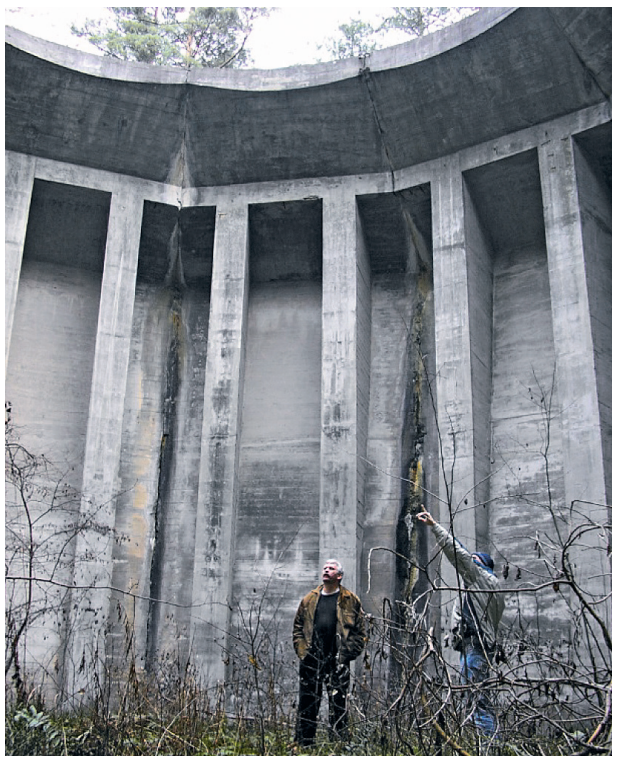

Fot. 3. Silos o nieznanym przeznaczeniu

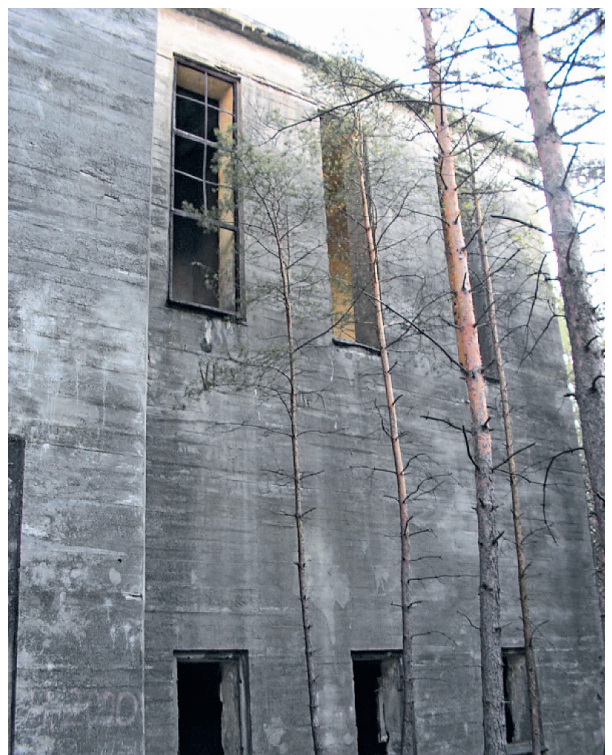

Fot. 4. Budynek elektrociepłowni

Na terenie obecnego Zakładu Karnego w Krzywańcu stacjonowała załoga ochraniająca teren kombinatu. Były to oddziały wartownicze liczące ok. 600 żołnierzy. Dla pracowników fachowych wybudowano dwa osiedla na terenie Krzystkowic. Ocenia się, że wykwalikowana kadra naukowa i techniczna oraz administracyjna liczyła kilkaset osób. Funkcjonujące wewnątrz kombinatu firmy m.in. budowlane, a także warsztaty produkcji pomocniczej w pełni zapewniały obsługę działów pomocniczych. Przymusowi robotnicy, zatrudnieni bezpośrednio przy produkcji materiałów wybuchowych, mieszkali w kilkunastu podobozach rozlokowanych w różnych częściach kompleksu fabrycznego.

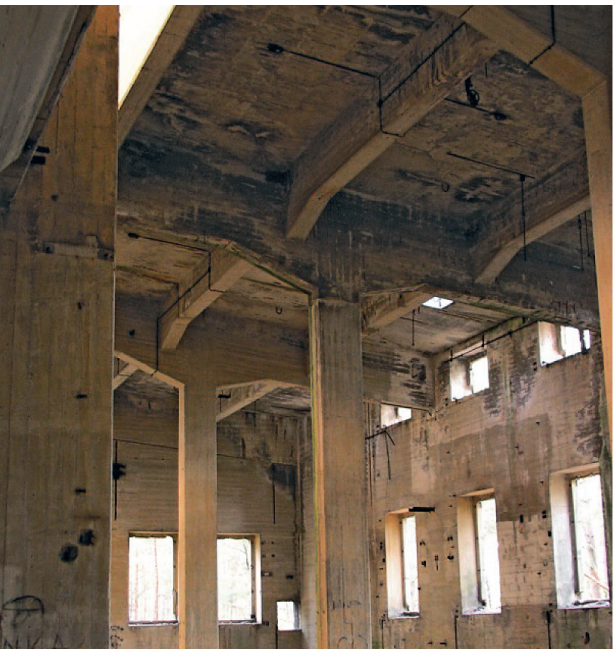

Fot. 5. Wnętrze budynku elektrociepłowni

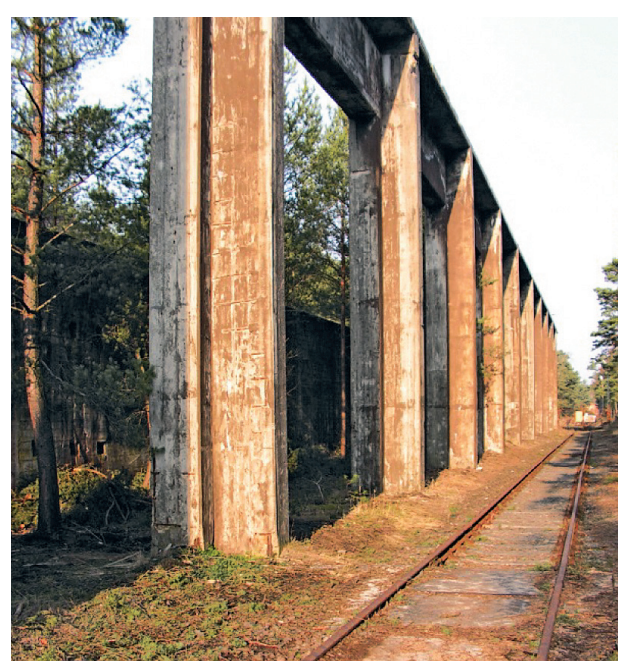

Fot. 6. Rampa rozładunkowa 
Zakłady zbrojeniowe w Krzystkowicach prowadziły produkcję wojskową na potrzeby hitlerowskich Niemiec. Ich działalność była pilnie strzeżona i utrzymana w ścisłej tajemnicy. Wobec braku odpowiedniej dokumentacji nie do końca jest znany profil produkcji kombinatu. Wiadomo, że produkowano tutaj materiały wybuchowe. Według niektórych źródeł w zakładach krzystkowickich odbywała się produkcja amunicji, głównie przeciwpancernej. Miano wyrabiać w nich przeciwpancerne granaty nasadkowe do granatnika karabinkowego. Nie wiadomo, czy był to pełny cykl technologiczny, czy tylko dokonywano napełniania amunicji, którą produkowano w innych zakładach.

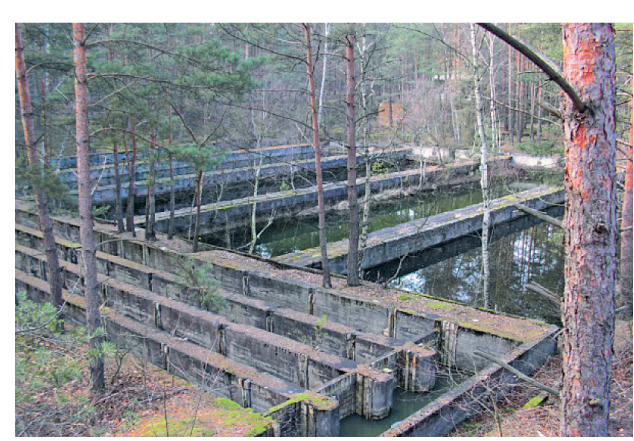

Fot. 7. Oczyszczalnia ścieków

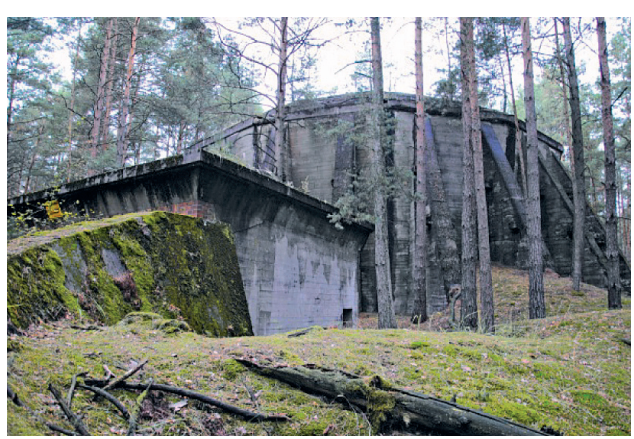

Fot. 8. Jeden z silosów o nieznanym przeznaczeniu

Obiekty Dynamit Aktien Gesellschaft nie były bombardowane przez aliantów, a produkcja materiałów wybuchowych trwała nieprzerwanie do początku 1945 roku. W lutym tego roku do Krzystkowic wkroczyła Armia Czerwona. Niemcy zdemontowali tylko część urządzeń i przetransportowali je w głąb Rzeszy. Pozostałe instalacje wywieźli najpierw Rosjanie, a następnie Wojsko Polskie. Niektóre urządzenia przewieziono do zakładów w Brzegu Dolnym, Zgierzu, Kędzierzynie, Poznaniu, Warszawie, Lublinie i Zamościu. W latach pięćdziesiątych XX wieku przystąpiono do rozbiórki części obiektów, przeznaczając materiał budowlany m.in. na odbudowę stolicy. Teren w dużym stopniu zniwelowano i posadzono na nim las sosnowy. Część dawnej fabryki zajęła jednostka Ludowego Wojska Polskiego. W niektórych budynkach znajdujących się na terenie Krzywańca zlokalizowano więzienie dla kobiet.

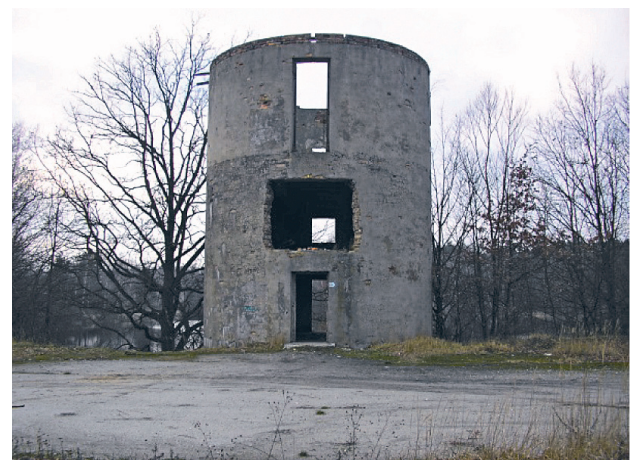

Fot. 9. Wieża basenu uzdatniania wody

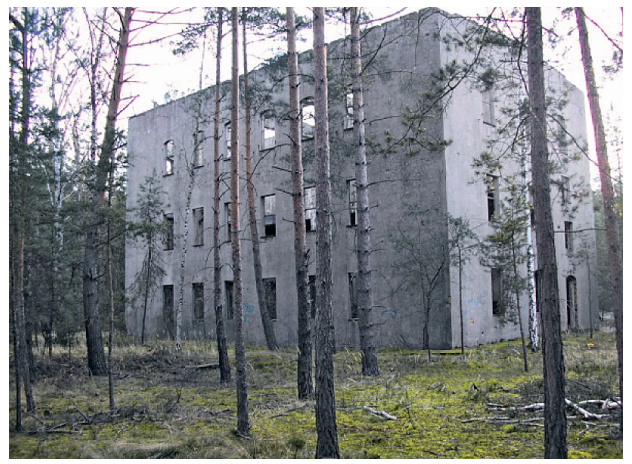

Fot. 10. Budynek przy basenie uzdatniania wody 


\section{Obiekty po zakladach DAG - stan obecny}

Budynki znajdujące się pod zarządem Nadleśnictwa Krzystkowice, pozbawione możliwości ciągłego i bezpośredniego nadzoru, od lat ulegają destrukcji wskutek działania niekorzystnych warunków atmosferycznych oraz dewastacji dokonywanych przez ludzi.

Znajdujące się na tym terenie budowle można zaliczyć do kilku kategorii ze względu na ich stan techniczny:

1. Obiekty o zachowanych fundamentach i całkowicie zniszczonej części naziemnej. Należy do nich najliczniejsza grupa zrujnowanych budynków, których rozbiórka miała miejsce zarówno bezpośrednio po zakończeniu drugiej wojny światowej, jak i w następnych latach, aż do czasów współczesnych. Ich funkcja obecnie nie jest możliwa do ustalenia.

2. Pozostałości budynków o częściowo zachowanych elementach naziemnych - fragmentach ścian i konstrukcji nośnych żelbetowych. Stanowią one duże zagrożenie dla osób odwiedzających ruiny. Podobnie jak obiekty poprzedniej kategorii, stojące w strefie przemysłowej, nie mają one określonej funkcji pierwotnej. Część budynków była wzniesiona na terenie obozów jenieckich. Najpewniej zajmowały je służby wartownicze i administracja obozowa. Po samych barakach nie pozostał żaden ślad.

3. Grupa stosunkowo najlepiej zachowanych budowli. Należą do niej niektóre dawne hale fabryczne, stacje transformatorowe, budynki elektrociepłowni, zbiorniki oraz niektóre obiekty związane z dostarczaniem wody i jej wykorzystaniem do celów technologicznych (ujęcia, baseny, przepompownie).

4. Obiekty podziemne: instalacje wodociągowe i kanalizacyjne, a także schrony. Obecność sieci wodociągowej i kanalizacyjnej na powierzchni potwierdzają otwory studzienek kontrolnych, w znacznym stopniu nie zabezpieczone i pozbawione włazów. Schrony widoczne na powierzchni jako niewielkie wzgórki, niektóre zachowane w całości, to nieduże obiekty jednokomorowe, pozwalające na ukrycie się nielicznej grupy ludzi. Generalnie ich stan można określić jako dobry.

5. Obiekty komunikacji wewnętrznej. Reprezentuje je przede wszystkim gęsta sieć dróg betonowych, do dziś zachowanych w stanie dobrym. Linia kolejowa, w czasie funkcjonowania kombinatu znacznie rozbudowana, do dziś przetrwała w stanie szczątkowym. Czynna jest tylko jedna bocznica prowadząca do jednostki wojskowej. Pozostałe bocznice zostały całkowicie rozebrane.

6. Ogrodzenie fabryki i obozów pracowników przymusowych. Praktycznie dawne ogrodzenie nie istnieje. W zasadzie zachowały się tylko ceglane słupy bramne.

\section{Posumowanie}

Obiekty po dawnym kombinacie zbrojeniowym Dynamit Aktien Gesellschaft w Krzystkowicach to wyjątkowy zespół w skali europejskiej o dużej wartości historycznej i naukowej. Pomimo dewastacji wielu budynków duża część obiektów jest zachowana w dobrym stanie. Czytelne jest też jeszcze rozplanowanie fabryki.

Brak możliwości zachowania i odpowiedniego utrzymania znacznych partii kompleksu zmusza do szukania rozwiązań, które umożliwiłyby uratowanie przed dewastacją obiekty znajdujące się w najlepszym stanie technicznym i jednocześnie zróżnicowane pod względem funkcjonalnym. Budynki naziemne o dobrze zachowanej konstrukcji powinny być 
bezzwłocznie zabezpieczone przed penetracją i dewastacją przez okolicznych mieszkańców i poszukiwaczy przedmiotów historycznych a także poddane stałemu dozorowi. Jednocześnie postuluje się przeprowadzenie badań historycznych, a w szczególności kwerendy archiwalnej i bibliograficznej pod kątem rozpoznania historii budowy kombinatu i jego funkcji jako zespołu. Ważne jest też ustalenie pierwotnego przeznaczenia obiektów o nieznanej dotychczas funkcji.

Za konieczne uważa się przeprowadzenie inwentaryzacji wybranych obiektów oraz dokonanie oceny ich stanu technicznego. Najwłaściwszym rozwiązaniem problemu związanego z utrzymaniem poszczególnych budynków byłoby opracowanie ogólnego planu ich zagospodarowania, a następnie znalezienie dla nich stałych użytkowników. Wśród obiektów o powtarzającej się funkcji (np. stacje transformatorowe) można dokonać wyboru tych budynków, które byłyby reprezentatywne dla poszczególnych kategorii i najlepiej nadawałyby się do ponownego użytkowania.

W związku z rosnącym zainteresowaniem fabryką ze strony miłośników historii przemysłu zbrojeniowego i fortyfikacji postuluje się opracowanie trasy turystycznej, umożliwiającej zapoznanie się z historią krzystkowickich zakładów i bezpieczną prezentację wybranych obiektów pofabrycznych.

\section{Literatura}

[1] Adamczewski L. Kombinat imieniem Nobla. Głos Wielkopolski z 9 lipca 1997 r.

[2] Adamczewski L. Złowieszcze widmo DAG-Alfred Nobel. Głos Wielkopolski z 25 sierpnia $1997 \mathrm{r}$.

[3] Chajewski D. Tajemnica przed wybuchem. Gazeta Lubuska z 27 listopada 1999 r.

[4] Panufnik J. Dynamit A.-G. Część I. Zarys stanu badań. Zielona Góra 1998 (maszynopis).

[5] Panufnik J. Krzystkowicki einmannek. Fortyfikacje na Ziemi Lubuskiej. Materiały z sesji naukowo-konserwatorskiej zorganizowanej przez Zielonogórski Oddział Towarzystwa Przyjaciół Fortyfikacji, Zeszyt sesyjny nr 3, Zielona Góra 1997, s. 32-33.

[7] Wojecki M. Tajemnicze obiekty. Magazyn Lubuski, nr 5 z 1994.

\section{The arms factory Dynamit Aktien Gesellschaft in Krzystkowice (Christianstadt). A history to be written again}

\section{Wojciech Eckert}

Institute of Structural Engineering, Faculty of Civil Engineering, Architecture and Environmental Engineering, University of Zielona Góra, e-mail: w.eckert@ib.uz.zgora.pl

\footnotetext{
Abstract: In the Lubusz Voivodship there are a large number of historical fortifications and buildings related to the arms industry. These objects, built in the first half of the 20th century as concrete structures, have lost their original function and character. They are disused and their condition is slowly deteriorating. One of them is the so-called "Dynamite Factory", a group of about 300 buildings scattered over a forest area of $35 \mathrm{~km}^{2}$, near Nowogród
} 
Bobrzański, about $20 \mathrm{~km}$ south of Zielona Góra. Some of them were blown up after World War II. However, many of them have been preserved in good condition to this day.

No serious, comprehensive studies regarding the "Dynamite Factory" in Krzystkowice have been conducted so far in terms of history, architecture or urban planning. There are not any ideas about the possibility and method of adapting the factory relics for modern purposes.

The article attempts to describe this huge factory complex. It also emphasizes that this building complex is unique not only in the voivodship but also in the whole region. A comprehensive programme for adaption, modernization and new, rational management of the factory relics should be prepared.

This kind of programme can involve both national and European, scientific units, architectural and urban studios, universities, local government units and many others. The Dynamit Aktien Gesellschaft arms factory in Krzystkowice (Christianstadt) is waiting for re-use, this time for peaceful purposes.

Keywords: historical object, dynamite factory, adaption, modernization, land development. 